\title{
H3C14 wt Allele
}

National Cancer Institute

\section{Source}

National Cancer Institute. H3C14 wt Allele. NCI Thesaurus. Code C154646.

Human H3C14 wild-type allele is located in the vicinity of $1 \mathrm{q} 21.2$ and is approximately 2 $\mathrm{kb}$ in length. This allele, which encodes histone H3.2 protein, is involved in the formation of complex DNA-containing structures. 